\title{
Petrological features of selected components of the Cergowa sandstones (Outer Carpathians) recorded by scanning electron microscopy - preliminary study
}

\author{
Joanna Pszonka ${ }^{1, *}$ \\ ${ }^{1}$ Mineral and Energy Economy Research Institute, Polish Academy of Sciences, 31-261 Krakow, \\ Poland
}

\begin{abstract}
The scanning electron microscope analysis of the Cergowa sandstones brings new data on their petrological features and chemical composition. Previous work in standard petrographic examination, e.g. polarising (PL) or cathodoluminescence (CL) microscopy, displayed limited information on grain surface topography and only assumptions to their geochemistry. Both identification and characterisation of minerals are fundamental in the progress of mining and minerals processing systems. Detrital grains of the Cergowa sandstones are bound by calcite and dolomitic cement and commonly corroded by diagenetic fluids, however, in varying degrees, which is illustrated here by feldspar, quartz and dolomite minerals. Dissolution processes of marginal parts of these mineral grains resulted in corrosion, which increased the contact surface between the grains and the cement. The difference in resistance to these processes was observed not only among distinct groups of minerals, but also within the group of feldspars: between $\mathrm{K}$-feldspars and minerals of plagioclase. That combination resulted in exceptionally strong cementation of the Cergowa sandstones, which is expressed by their high hardness and resistance to abrasion, freezing, and thawing. Inherent parameters of sandstones are characterised by their petrographical properties.
\end{abstract}

\section{Introduction}

Previous studies about the Cergowa sandstones, conducted mainly by using polarising (PL) or cathodoluminescence (CL) microscopy [1-4], clearly demonstrate advantages of complementary approaches to its petrographic properties. As an example, cathodoluminescence microscopy proved to be a very usable and even indispensable method in studying the Cergowa sandstones and thereby often reveals features not distinguished by other techniques [3, 4]. Nevertheless, CL microscopy also demonstrates difficulties in obtaining some data, e.g. the geochemical composition of single detrital grains and surrounding cement [4]. Used techniques in the Cergowa sandstones petrology did not enable more detailed description of a chemical composition of rock components,

*Corresponding author: jpszonka@min-pan.krakow.pl 
thereby allowed for assumptive identification of minerals. The combination of CL imaging with CL spectroscopy proved even some difficulties in the study material because of too small grains size. Furthermore, luminescence of carbonates, which constitute a large proportion of these sandstones, is brighter than other components such as silicate minerals, which in such conditions show little or no luminescence.

Benefits and weaknesses of used methods have prompted research with supplementary techniques: "Further work, including geochemical investigations (...) should be conducted in the future" [3]. Scanning electron microscope (SEM) was chosen to further investigation, because provides higher magnifications, better detection and more stable operating conditions than conventional techniques. The scanning electron microscopy enables to obtain three-dimensional images of individual sediments grains of the Cergowa sandstones and their chemical composition. Such results significantly complete foregoing research of the Cergowa sandstones petrology $[1,2,4]$.

\section{Material and methods}

The Cergowa sandstones (Lower Oligocene) constitute the main part of the lithosome Cergowa Beds and are situated within the Dukla and Fore-Dukla tectonic unit of the Eastern Outer Carpathians [5-7]. The Cergowa sandstones represent sediments deposited by a variety of mass gravity flows as submarine fan or fans [8-11] and were classified as greywackes or lithic wackes and arenites $[1,2]$.

Samples of the Cergowa sandstones were collected from outcrops at five locations: four from the Dukla tectonic unit (Iwla, Lipowica, Stasiana and Wernejówka) and one from the Fore-Dukla tectonic unit (Rudawka Rymanowska). Hand specimens of sandstones for SEM examination were crushing to give pieces of suitable size (a few millimetres) for mounting. Each sample was glued to the stub $(1 \mathrm{~cm}$ in diameter) and coated with carbon to provide conduction. In total, 10 samples were analysed. Chemical composition of minerals was detected by the energy dispersive spectroscopy (EDS), using standard analytical algorithms, where the element concentrations are normalized to $100 \%$.

Investigation was performed at the SEM-Laboratory in the Geological Institute at the TU Bergakademie Freiberg with the usage of the Jeol JSM 7001F scanning electron microscope. The imaging was carried out in the Back Scattered Electron (BSE) Bruker, Esprit 1.9.3. with following parameters: accelerating voltage of $15 \mathrm{keV}$, electron beam current of $10 \mu \mathrm{A}$, and working distance $12-14 \mathrm{~mm}$.

\section{Results}

\subsection{Feldspars}

SEM images of feldspars display difference between a grain surface morphology of Kfeldspars and plagioclases. The grain surface topography of $\mathrm{K}$-feldspars shows more intense etching and is generally rougher than that of plagioclases (Fig. 1, top). Emission bands, under the SEM image, enable to identify and distinguish both mentioned feldspars (Fig. 1, middle and bottom). 

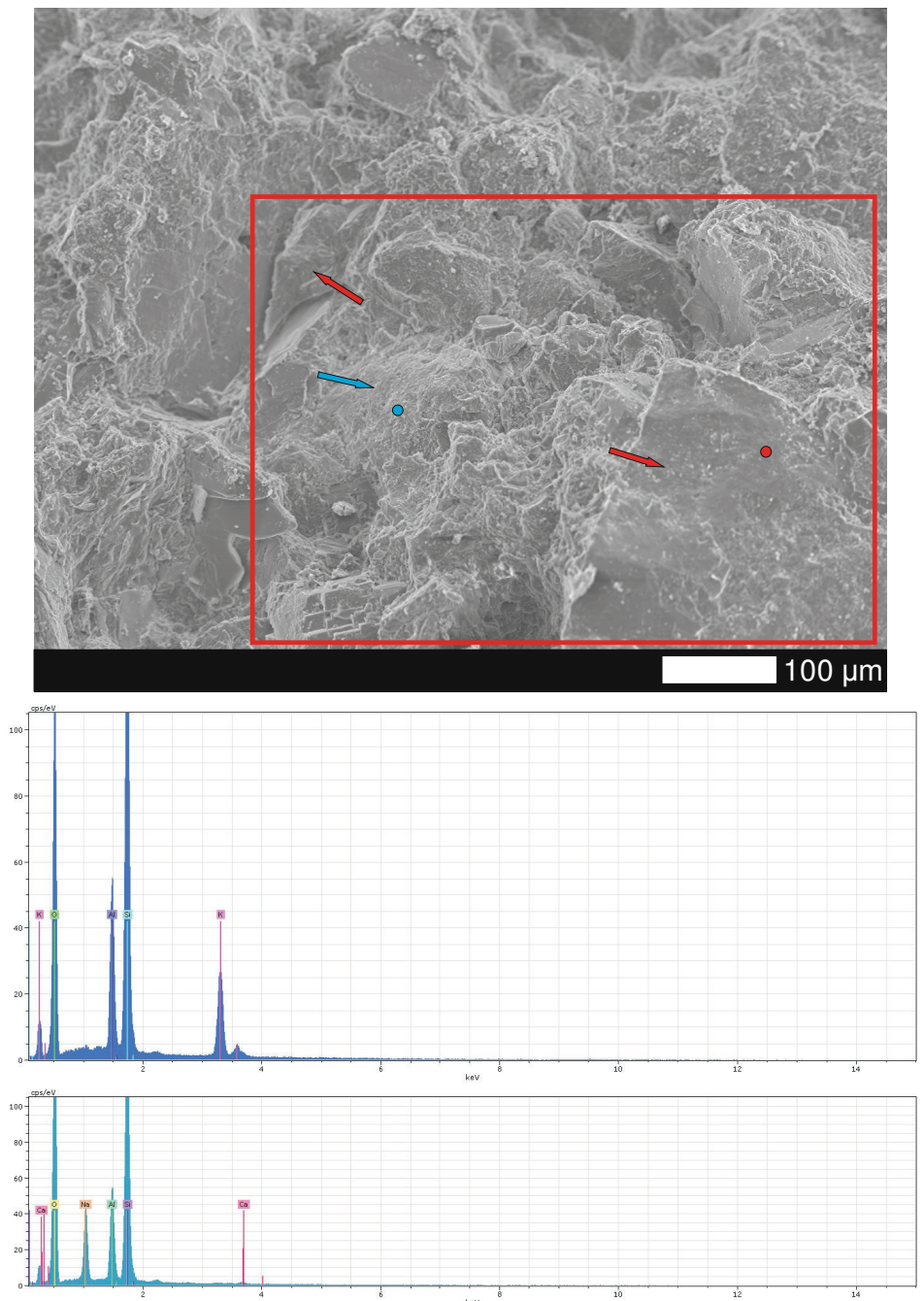

Fig. 1. Top - SEM image of feldspar minerals: blue arrow points to K-feldspar, red arrows point to minerals of plagioclase solid solution. Middle - Emission band displays chemical composition of the $\mathrm{K}$-feldspar recorded in the blue spot. Bottom - Emission band displays chemical composition of the plagioclase recorded in the red spot.

\subsection{Quartz}

Quartz belongs to the most abundant group of minerals in the Cergowa sandstones. However, due to short-lived luminescence colours, brownish colour or no luminescence of quartz from tectonically active region, it was often overlooked in cathodoluminescence studies. Surface relief of quartz in SEM images, is marked by few trails of dissolution (Fig. 2, top and 3). Even some irregularly etched quartz grains indicate their high resistance and/or low intensity for weathering and diagenetic processes. Emission band in the figure 2 (bottom) distinguishes quartz among remaining components of the sandstone. 

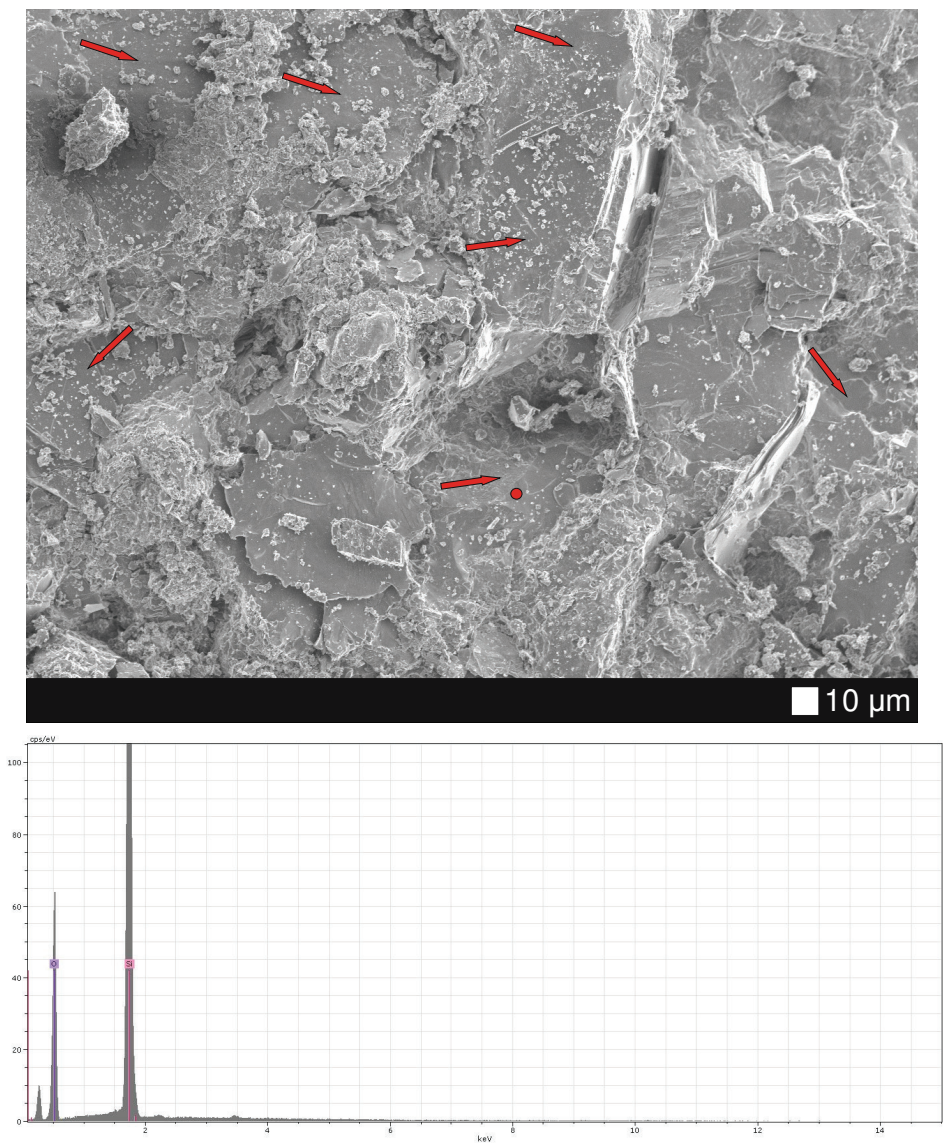

Fig. 2. Top - SEM image of quartz pointed by red arrows. Bottom - Emission band displays chemical composition of quartz recorded in the red spot.

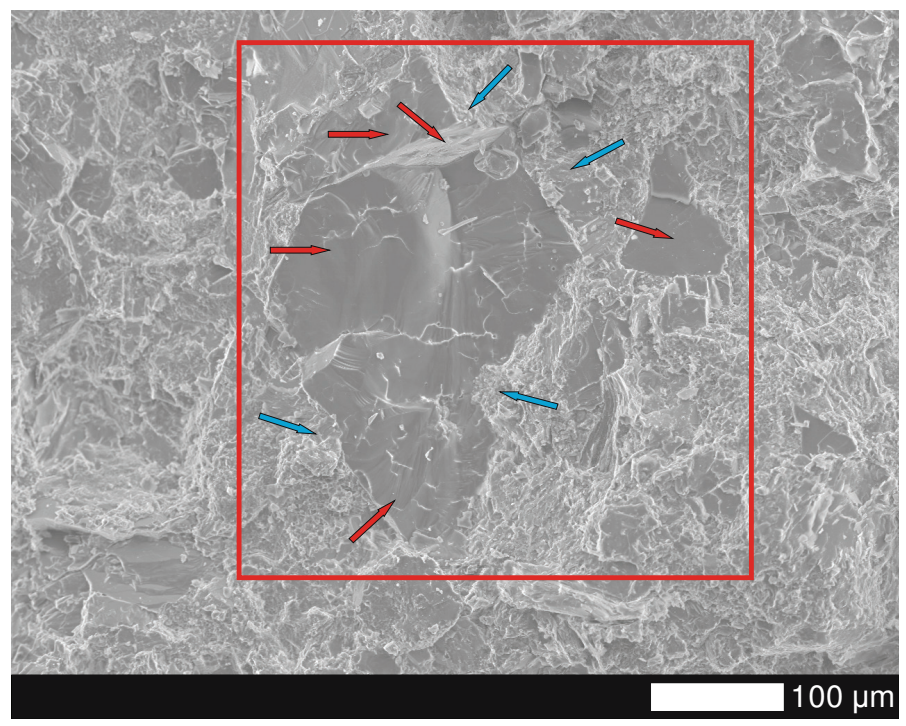

Fig. 3. SEM image of quartz pointed by red arrows and carbonate cement pointed by blue arrows, surrounding quartz grains. 


\subsection{Dolomites}

Dolomites in the Cergowa sandstones occur as lithic grains and cement. Cathodoluminescence imaging allowed recognising polycrystalline detrital grains of dolostone as well as monocrystals occurring as detrital components and cement [4]. However, using CL imaging without spectroscopy it was only possible to estimate the chemical composition of the Cergowa sandstones components.

The SEM visualisation has revealed finely, rhomb-shaped, densely packed, euhedral to subeuhedral dolomite crystals which constitute cement in the Cergowa sandstones (Fig. 4 and 5), and random, solitary, larger dolomite grains, which are identifiable by rhomboidal shape and etched surface morphology and represent detrital components (Fig. 4 and 6). Moreover, the relationship between calcite and dolomite cement is here clearly seen (Fig. 5), whilst in standard techniques it is obliterated [4]. The chemical composition of detrital and authigenic dolomite is illustrated by emission bands in figure 4 (bottom) and 5 (bottom).
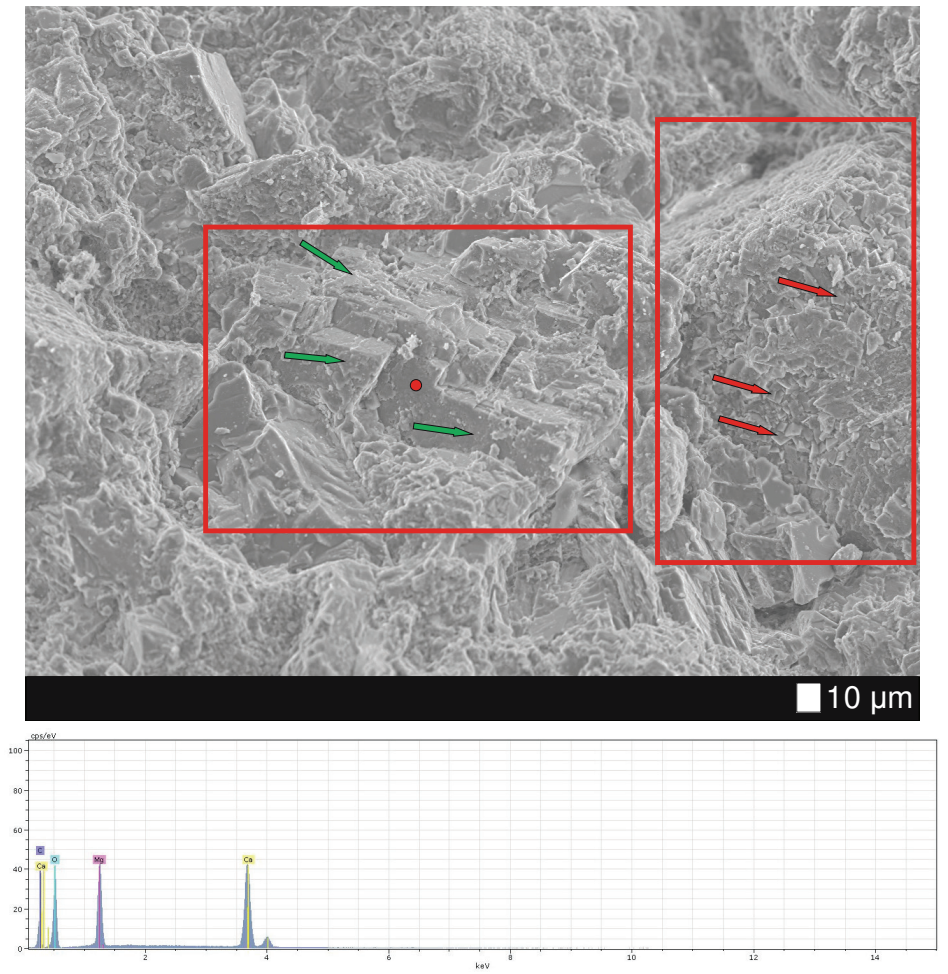

Fig. 4. Top - SEM image of randomly distributed detrital grain of dolomite pointed by green arrows and finely, densely packed, euhedral to subeuhedral dolomitic cement pointed by red arrows. Bottom - Emission band displays chemical composition of detrital dolomite recorded in the red spot. 

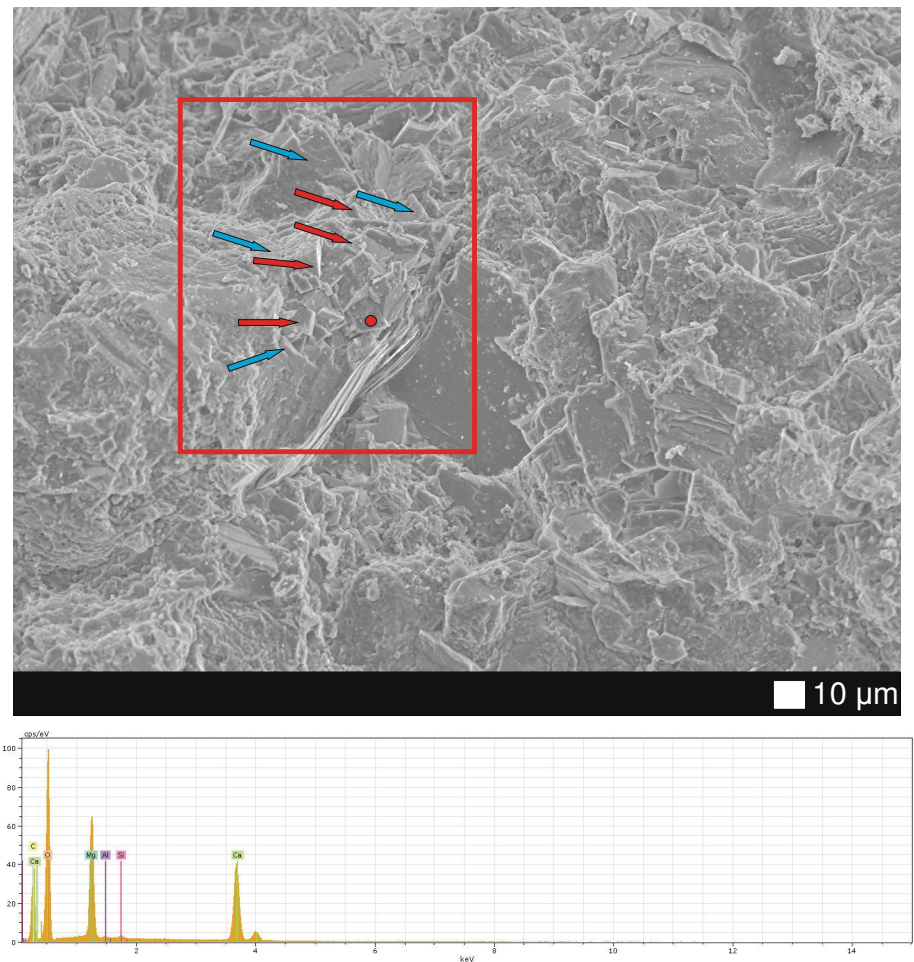

Fig. 5. Top - SEM image of finely, densely packed, euhedral to subeuhedral dolomitic cement pointed by red arrows, surrounded by calcite cement pointed by blue arrows. Bottom - Emission band displays chemical composition of dolomitic cement recorded in the red spot.

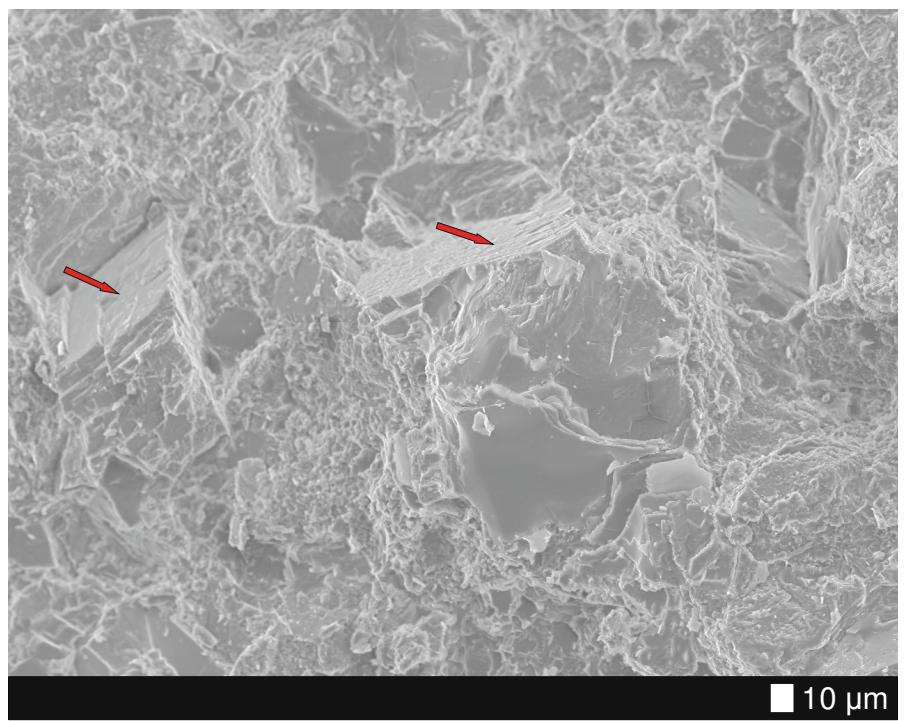

Fig. 6. SEM image of randomly distributed detrital grains of dolomite (pointed by red arrows) with partly abraded surface morphology. 


\section{Discussion}

The etching, embayment and partial replacement of the Cergowa sandstones grains during carbonate precipitation are more and more imaged and known, simultaneously reflect conditions in which dissolution was produced. Acidic pore waters had destructive effect on all minerals of the framework, with simultaneous precipitation of carbonate material [1-4]. Growth of calcite in place of pre-existing detrital grains is very clearly visible in SEM images of the Cergowa sandstones.

The acidic environment was favourable for dissolution and destruction of detrital grains but with varying intensity. SEM results in this publication visualize this diversity, which is displayed not only among different groups of minerals such as feldspar, quartz and dolomite, but even in the field of feldspars. Obtaining such visualisation was indistinct by using polarizing (PL) and cathodoluminescence (CL) microscopes. Thereby, the CL imaging of feldspar minerals replacement by carbonate cement $[3,10]$ presumably relates to $\mathrm{K}$-feldspars and not to the whole group of feldspars as reported in the cited publications. Besides low and moderate stage in etching of quartz and dolomite verify results of the previous works in standard petrographic techniques in regard to low intensity of dissolution $[1]$.

Despite its modest intensity, this process was very important for the sediment lithification. It resulted in increased surface of the corroded grains, and therefore stronger cementation of the components, which is manifested by high hardness and resistance of the Cergowa sandstones $[12,13]$.

\section{Conclusions}

1. The SEM analyses enabled to document new petrological features of the Cergowa sandstones, which the PL and CL observations do not reveal, such as:

- chemical composition of components,

- difference between a surface relief of K-feldspars and plagioclases,

- sporadically and irregularly etched quartz grains indicating their high resistance,

- visualisation of variety in shapes and size of dolomite.

2. Dissolution was important for the sediment lithification by increasing the surface of contact between corroded grains and carbonate cement; this resulted in very strong cementation of the Cergowa sandstones.

3. This study shows that the SEM analysis and the standard petrographic techniques, as PL and CL microscopy, should be considered as complementary techniques.

Many thanks to Anja Obst (TU Bergakademie Freiberg) who helped with the scanning electron microscope analyses, which were funded by the Post-Doctoral Research Grant of the International Association of Sedimentologists 2016/2017 for PhD Joanna Pszonka.

\section{References}

1. C. Peszat, Variations of mineral composition of the Cergowa sandstones in the light of their deposition conditions and diagenetic alterations (in Polish with English abstract), Biuletyn Państwowego Instytutu Geologicznego, 346, 24, 207-234 (1984)

2. J. Pszonka, The influence of sedimentation and diagenetic processes on economic significance of the Cergowa sandstones from "Lipowica II-1" deposit, Gospod. Surowcami Min. 25, 3, 333-342 (2009) 
3. J. Pszonka, M. Wendorff, Gospod. Surowcami Min. 30, 4, 21-36 (2014) doi: 10.2478/gospo-2014-0036

4. J. Pszonka, M. Wendorff, Int. J. Earth Sci. 106, 269-282 (2017) doi: 10.1007/s00531016-1318-Z

5. M. Cieszkowski, A. Ślączka, W. Zuchiewicz, Detailed geological map of Poland 1:50000, Jaśliska sheet (PGI, Warszawa, 1990)

6. A. Ślączka, On the possibility of occurrence of bitumen deposits in the western part of the Dukla Unit in the Polish Eastern Carpathians (in Polish with English abstract), Geol. Q. 12(2): 344-249 (1970)

7. A. Slączka, The Geology of the Dukla Unit, Polish Flysch Carpathians (PGI, Warszawa, 1971)

8. D. Dirnerová, M. Prekopová, J. Janocko, Geol. Q. 56, 3, 547-560 (2012) doi: 10.7306/gq. 1039

9. P.S. Dziadzio, Z. Borys, S. Kuk, E. Masłowski, J. Probulski, M. Pietrusiak, A. Górka, J. Moryc, P. Karnkowski, P.H. Karnkowski, M. Pietrusiak, Hydrocarbon resources of the Polish Outer Carpathians - reservoir parameters, trap types and selected hydrocarbon fields: A. Stratigraphic Review (AAPG, Tulsa, 2006)

10. J. Pszonka, Studium sedymentologiczne warstw cergowskich $w$ jednostce dukielskiej $i$ przeddukielskiej Karpat fliszowych (IGSMiE PAN, Krakow, 2015)

11. A. Slączka, R. Unrug, Trends of textural and structural variation in turbidite sandstones: the Cergowa Sandstone (Oligocene, Outer Carpathians), Ann. Soc. Geol. Pol. 46, 55-76 (1976)

12. C. Peszat, M. Buczek-Pułka, Znaczenie surowcowe piaskowców cergowskich na tle ich właściwości fizyczno-mechanicznych, Biuletyn Państwowego Instytutu Geologicznego, 351, 179-211 (1986)

13. J. Pszonka, M. Wendorff, E. Kusaj, Piaskowce. cergowskie jako najważniejszy surowiec skalny województwa podkarpackiego, Biuletyn Państwowego Instytutu Geologicznego, 439(2), 261-268 (2010) 